CD68 + macrophages were found to be closely associated with tumor cells, PD-L1+ macrophages were found to have the closest interaction with tumor cells. The potential of these cell phenotypes to generate a strongly immunosuppressive microenvironment need to be explored in additional cases.

http://dx.doi.org/10.1136/jitc-2020-SITC2020.0547

\section{CD8+ TISSUE-RESIDENT MEMORY T CELLS ARE TUMOUR REACTIVE AND INCREASE AFTER IMMUNOTHERAPY IN A CASE OF METASTATIC MUCOSAL MELANOMA}

\begin{abstract}
${ }^{1}$ Angela Pizzolla*, ${ }^{1}$ Simon Keam, ${ }^{1}$ Ismael Vergara, ${ }^{1}$ Franco Caramia, ${ }^{1}$ Minyu Wang, ${ }^{1}$ Nikolce Kocovski, ${ }^{1}$ ThuNgoc Nguyen, ${ }^{1}$ Sean Macdonald, ${ }^{1}$ Daniela Tantalo, ${ }^{1}$ Pasquale Petrone, ${ }^{1}$ Han Xian Aw Yeang, 'David Gyorki, 'Alison Weppler, 'George AuYeung, 'Shahneen Sandhu, ${ }^{2}$ Maurizio Perdicchio, ${ }^{1}$ Grant McArthur, ${ }^{1}$ Tony Papenfuss, ${ }^{1}$ Paul Neeson. ${ }^{1}$ Peter MacCallum Cancer Centre, Melbourne, Australia; ${ }^{2}$ F. Hoffmann - La Roche Ltd, Seattle, WA, United States
\end{abstract}

Background Mucosal melanoma is a rare subtype of melanoma originating from mucosal tissues, ${ }^{1}$ metastases are very aggressive and respond poorly to therapy, including immune checkpoint inhibitors (ICI) such as anti-CTLA4 and anti-PD1 antibodies. $^{2-5} \mathrm{CD} 8+\mathrm{T}$ cells constitute the most abundant immune infiltrate in metastatic melanoma, of which the Tissue Resident Memory subset (TRM) is of particular interest. ${ }^{6}$ CD8 + TRM cells express the highest levels of immune checkpoint receptors, proliferate in response to ICI and correlate with longer disease-free and overall survival. ${ }^{6-8}$ The immune landscape in mucosal melanoma remains poorly characterized. We aimed to: 1) phenotype CD8 $+\mathrm{T}$ cells and TRM infiltrating metastatic mucosal melanoma, 2) characterize the clonality of TRM in relation to other CD8 $+\mathrm{T}$ cell subsets and 3) define the capacity of CD8 $+\mathrm{T}$ cells and TRM to respond to melanoma cells and to in vivo and in vitro anti-PD1 treatment.

Methods We investigated the CD8 + T and TRM cells infiltrating two temporally- and spatially-distant subcutaneous metastases, these originated from a primary vaginal mucosal melanoma. One metastasis was excised prior to anti-PD1 treatment and one was anti-PD1 refractory, having progressed on treatment. We used mass cytometry and single-cell RNA and TCR sequencing to characterise the phenotype and clonality of the $\mathrm{T}$ cells, multiplex immunohistochemistry to define their spatial relationship with tumour cells and other $\mathrm{T}$ cells, and functional assays to determine TRM response to tumour cells (figure 1).

Results CD8 + TRM frequency increased with time and antiPD1 treatment, forming clusters at the tumour margin. T cells in the anti-PD1 refractory lesion were more activated than $\mathrm{T}$ cells in the first tumour and were bound by anti-PD1 antibody in vivo. $\mathrm{T}$ cells could not be stimulated by anti-PD1 directly ex vivo. Both metastatic lesions shared common $\mathrm{T}$ cell clusters including TRM. Furthermore, TRM in each tumour shared $\mathrm{T}$ cell clones, suggesting the presence of common antigens between metastatic sites. Indeed, the two metastases had a similar mutational profile. In vitro expanded tumour infiltrating lymphocytes from both lesions recognized tumour cells from both lesions and the same neoantigen generated from a single point mutation in the gene CDKN1C. Finally, tumour cells stimulated TRM cells more robustly than other $\mathrm{T}$ cells subsets.

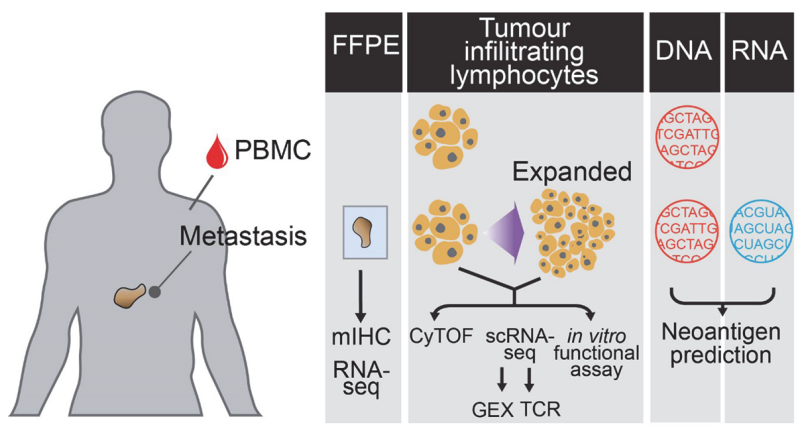

Abstract 548 Figure 1 Graphical depiction of the methods used to characterise $T$ cells in mucosal metastatic melanoma

Conclusions In this patient with vaginal mucosal melanoma, subsequent melanoma metastases of clonal origin attracted CD8 + T cells of similar specificity, among which TRM cells responded more vigorously to tumour cells than other $\mathrm{T}$ cells subsets.

Acknowledgements The authors would like to acknowledge imCORE La Hoffmann- Roche Ltd. for funding.

Ethics Approval Patients diagnosed with stage 3 or 4 metastatic melanoma and undergoing clinically indicated surgery were enrolled in prospective studies approved by the Peter MacCallum Cancer Centre human ethics research committee (13/141). All experimental protocols have been approved and clinical data has been collected prospectively.

\section{REFERENCES}

1. Carvajal RD, Hamid O, Ariyan C. Mucosal Melanoma. [cited 2020 Apr 1]; Available from: https://www.uptodate.com/contents/mucosal-melanoma

2. Del Vecchio M, Di Guardo L, Ascierto PA, Grimaldi AM, Sileni VC, Pigozzo J, et al. Efficacy and safety of ipilimumab $3 \mathrm{mg} / \mathrm{kg}$ in patients with pretreated, metastatic, mucosal melanoma. Eur J Cancer Oxf Engl 1990;2014 Jan;50(1):121-7.

3. Postow MA, Luke JJ, Bluth MJ, Ramaiya N, Panageas KS, Lawrence DP, et al. Ipilimumab for patients with advanced mucosal melanoma. The Oncologist 2013 Jun;18(6):726-32.

4. D'Angelo SP, Larkin J, Sosman JA, Lebbé C, Brady B, Neyns B, et al. Efficacy and safety of nivolumab alone or in combination with ipilimumab in patients with mucosal melanoma: a pooled analysis. J Clin Oncol Off J Am Soc Clin Oncol. 2017 Jan 10;35(2):226-35.

5. Hamid O, Robert C, Ribas A, Hodi FS, Walpole E, Daud A, et al. Antitumour activity of pembrolizumab in advanced mucosal melanoma: a post-hoc analysis of KEYNOTE-001, 002, 006. Br J Cancer 2018;119(6):670-4.

6.. Boddupalli CS, Bar N, Kadaveru K, Krauthammer M, Pornputtapong N, Mai Z, et al. Interlesional diversity of T cell receptors in melanoma with immune checkpoints enriched in tissue-resident memory T cells. JCI Insight [Internet]. 2016 Dec 22 [cited 2019 Apr 24];1(21). Available from: https://insight.jci.org/articles/view/ 88955

7. Edwards J, Wilmott JS, Madore J, Gide TN, Quek C, Tasker A, et al. CD103+ Tumor-resident CD8+ T cells are associated with improved survival in immunotherapy-naïve melanoma patients and expand significantly during anti-PD-1 treatment. Clin Cancer Res Off J Am Assoc Cancer Res 2018 Jul 1;24(13):3036-45.

8. Savas P, Virassamy B, Ye C, Salim A, Mintoff CP, Caramia F, et al. Single-cell profiling of breast cancer $T$ cells reveals a tissue-resident memory subset associated with improved prognosis. Nat Med 2018 Jul;24(7):986-93.

http://dx.doi.org/10.1136/jitc-2020-SITC2020.0548

\section{CHARACTERIZING DOUBLE POSITIVE T CELLS IN THE TUMOR MICROENVIRONMENT: A TALE OF PROMISCUOUS CELL FATES}

${ }^{1}$ Sara Schad*, ${ }^{1}$ Andrew Chow, ${ }^{2}$ Heng Pan, ${ }^{1}$ Levi Mangarin, ${ }^{1}$ Roberta Zappasodi, ${ }^{1}$ Mathieu Gigoux, ${ }^{2}$ David Redmond, ${ }^{1}$ Daniel Hirschhorn-Cymerman, ${ }^{1}$ Sadna Budhu, ${ }^{1}$ Hong Zhong, ${ }^{1}$ Xia Yang, ${ }^{2}$ Olivier Elemento, ${ }^{1}$ Jedd Wolchok, ${ }^{1}$ Taha Merghoub. ${ }^{1}$ MSKCC, New York, NY, USA; ${ }^{2}$ WCMC, New York, NY, USA 


\section{University Library}

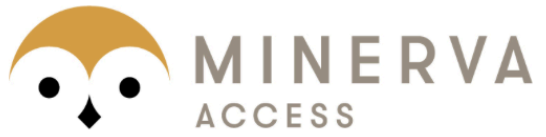

A gateway to Melbourne's research publications

Minerva Access is the Institutional Repository of The University of Melbourne

\section{Author/s:}

Pizzolla, A;Keam, S;Vergara, I;Caramia, F;Wang, M;Kocovski, N;ThuNgoc, N;Macdonald, S;Tantalo, D;Petrone, P;Yeang, HXA;Gyorki, D;Weppler, A;Au-Yeung, G;Sandhu, S;Perdicchio, M;McArthur, G;Papenfuss, T;Neeson, P

Title:

CD8+TISSUE-RESIDENT MEMORY T CELLS ARE TUMOUR REACTIVE AND INCREASE AFTER IMMUNOTHERAPY IN A CASE OF METASTATIC MUCOSAL MELANOMA

Date:

2020-11-01

\section{Citation:}

Pizzolla, A., Keam, S., Vergara, I., Caramia, F., Wang, M., Kocovski, N., ThuNgoc, N., Macdonald, S., Tantalo, D., Petrone, P., Yeang, H. X. A., Gyorki, D., Weppler, A., AuYeung, G., Sandhu, S., Perdicchio, M., McArthur, G., Papenfuss, T. \& Neeson, P. (2020). CD8+TISSUE-RESIDENT MEMORY T CELLS ARE TUMOUR REACTIVE AND INCREASE AFTER IMMUNOTHERAPY IN A CASE OF METASTATIC MUCOSAL MELANOMA. [Abstract]. JOURNAL FOR IMMUNOTHERAPY OF CANCER, 8 (Suppl 3), pp.A333-A333. https:// doi.org/10.1136/jitc-2020-SITC2020.0548.

Persistent Link:

http://hdl.handle.net/11343/273972

License:

CC BY-NC-ND 